UDC 631.1(091)(477)(478) "1969/1990"

DOI 10.24919/2519-058X.20.240032

\title{
Nataliia KOVALENKO
}

PhD hab. (History), Senior Researcher, Chief Researcher of Science Study Sector of Institute of History of Agrarian Science, Education and Technique of National Scientific Agricultural Library of National Academy of Agrarian Sciences of Ukraine, 10 Heroiv Oborony Street, Kyiv, Ukraine, postal code 03127 (boikonp@ukr.net)

ORCID: 0000-0002-0996-0732

ResearcherID: D-2429-2019

\section{Roman BEY}

PhD hab. (History), Senior Researcher, Chief Researcher of the Sector of Scientific Bibliography and Biography Study of Institute of History of Agrarian Science, Education and Technique of National Scientific Agricultural Library of National Academy of Agrarian Sciences of Ukraine, 10 Heroiv Oborony Street, Kyiv, Ukraine, postal code 03127 (bey.roman10@gmail.com)

ORCID: 0000-0003-0649-2141

\section{Наталія КОВАЛЕНКО}

доктор історичних наук, старший науковий співробітник, головний науковий співробітник сектору наукознавства Інституту історії аграрної науки, освіти та техніки Національної наукової сільськогосподарської бібліотеки Національної академії аграрних наук Украӥни, вул. Героїв Оборони, 10, м. Київ, Украӥна, індекс 03127 (boikonp@ukr.net)

\section{Роман БЕЙ}

доктор історичних наук, стариий науковий співробітник, головний науковий співробітник сектору наукової бібліографії та біографістики Інституту історї аграрної науки, освіти та техніки Національної наукової сільськогосподарської бібліотеки Національної академії аграрних наук України, вул. Героїв Оборони, 10, м. Київ, Украӥна, індекс 03127 (bey.roman10@gmail.com)

Bibliographic Description of the Article: Kovalenko, N. \& Bey, R. (2021). Southern Branch of the VASHNIL (1969 - 1990) as a Model of Organization of Agrarian Science in the Ukrainian and Moldavian SSR. Skhidnoievropeiskyi Istorychnyi Visnyk, 20, 162-170. doi: 10.24919/2519-058X.20.240032

\section{SOUTHERN BRANCH OF THE VASHNIL (1969 - 1990) AS A MODEL OF ORGANIZATION OF AGRARIAN SCIENCE IN THE UKRAINIAN AND MOLDAVIAN SSR}

\footnotetext{
Abstract. The aim of the research is to elucidate the main scientific and field cooperation areas of the Ukrainian and Moldavian SSR agrarian scientists under the auspices of the Southern Branch of V. I. Lenin All-Union Academy of Agricultural Sciences (Southern Branch of the VASHNIL), its
} 
activities and contribution to the development of agrarian science. The research methodology is based on the principles of historicism, system-formation, scientific character, the author's objectivity, and the use of general scientific (analysis, synthesis, generalization), special and historical (historical systemic, historical typological, etc.) methods. The scientific novelty consists in the fact that for the first time on the basis of previously unknown archival documents there have been highlighted the results of scientific and methodological activities of the Southern Branch of the VASHNIL, which aimed at organizing research in various scientific areas, taking into account zonal characteristics, specialization and concentration of agrarian production. The Conclusions. The cooperation of the Ukrainian and Moldavian scientists ensured the development of highly efficient technologies in farming and plant cultivation, plant selection and seed production, land reclamation and animal husbandry, mechanization and electrification, economics and organization of agrarian production. Systematic exchange of scientific information accelerated and increased the efficiency of practical implementation of research results in production. The results of research work of the Ukrainian and Moldavian scientists gained international recognition among scientists of the Soviet Union Republics and the countries of the Council for Mutual Economic Assistance. Their significant achievements provided an increase in international prestige and confirmation that domestic science occupied an honorable place abroad.

Key words: the Southern Branch of the VASHNIL, scientific cooperation, research institutions, high-performance technologies, practical implementation, agrarian production.

\title{
ПІВДЕННЕ ВІДДІЛЕННЯ ВАСГНІЛ (1969 - 1990) ЯК МОДЕЛЬ ОРГАНІЗАЦІЇ АГРАРНОЇ НАУКИ В УКРАЇНСЬКІЙ ТА МОЛДАВСЬКІЙ РСР
}

\begin{abstract}
Анотація. Мета дослідження-розкрити основні науково-галузеві напрями співпрачі вченихаграріїв Украӥнської та Молдавської РСР під егідою Південного відділення Всесоюзної академії сільськогосподарських наук імені В. І. Леніна (Південне відділення ВАСГНІЛ), його діяльність та внесок у розвиток аграрної науки. Методологія дослідження трунтується на принципах історизму, системності, науковості, авторської об'єктивності, а також на використанні загальнонаукових (аналіз, синтез, узагальнення) та спеціально-історичних (історикосистемний, історико-типологічний) методів. Наукова новизна полягає у тому, що вперше на основі невідомих раніше архівних документів висвітлено результати науково-методичної діяльності Південного відділення ВАСГНІЛ, яка спрямовувалась на організацію досліджень за різними науково-галузевими напрямами з урахуванням зональних особливостей, спеціалізації та концентрації аграрного виробництва. Висновки. Співпрачя українських та молдавських вчених забезпечувала опрачювання високоефективних технологій у землеробстві $i$ рослинництві, селекиії та насіннищтві, меліорації і тваринництві, механізаиї та електрифікащії, економіці $і$ організації сільськогосподарського виробництва. Систематичний обмін науковою інформацією прискорював та підвищував ефективність практичного впровадження результатів досліджень у виробництво. Результати науково-дослідницької роботи українських та молдавських вчених набули міжнародного визнання серед науковиів союзних республік $і$ крайн Ради Економічної Взаємодопомоги. Їх вагомі здобутки забезпечили зростання міжнародного авторитету та підтвердження, що вітчизняна наука займала почесне місие за кордоном.
\end{abstract}

Ключові слова: Південне відділення ВАСГНІЛ, наукова співпрачя, науково-дослідні установи, високопродуктивні технології, практичне впровадження, аграрне виробництво.

The Problem Statement. The Southern Branch of V. I. Lenin All-Union Academy of Agricultural Sciences (the Southern Branch of VASHNIL) functioned during 1969 - 1990, as a scientific methodical and coordination center with a strong material and technical base and a qualified scientific team. Owing to its effective management, technical progress in agriculture was ensured, methods of scientific research were improved, achievements of science and the best practices were generalized. Cooperation with the Academies of Sciences of the Ukrainian and Moldavian SSRs, ministries and departments of the countries was strengthened in the direction of conducting joint research, organizing scientific and technical 
relations with foreign academies, research institutions and institutions of higher education. Taking into account the research scale, in the context of European integration, there has been updated the direction of results coverage of scientists cooperation during the activities of the Southern Branch of VASHNIL, as a scientific methodical and coordination center, which united research institutions and institutions of higher education according to the main scientific and branch areas in the Ukrainian and Moldavian SSRs.

The Analysis of Sources and Recent Researches. V. Verhunov analyzed the peculiarities of the system development of branch scientific researches in Ukraine, determined the formation stages of knowledge about these processes(Verhunov, 2012). During the period of activity of the Southern branch of VASHNIL V. Orekhivskyi analyzed the features of agrarian science development in the context of working out of organic agriculture scientific technologies (Orekhivskyi, 2018), S. M. Basil and V. M. Kryzhanivsky analyzed the cooperation results of scientists of the All-Union Research Institute of Bast Cultures and scientists of the Hungarian People's Republic (Basyl \& Kryzhanivskyi, 2019). S. Nyzhnyk clarified the organizational role in the institution formation of V. F. Peresypkin, its founder, a corresponding member of VASHNIL (Nyzhnyk, 2014). O. O. Chernysh elucidated the institution organizational structure and certain areas of activity (Chernysh, 2012). However, the researchers did not do a comprehensive analysis of the agricultural science development under the auspices of the Southern Branch of VASHNIL, they did not analyze the cooperation results between the Ukrainian and Moldavian agricultural scientists in scientific and branch areas coordinated by sections of the institution.

The Purpose of Publication is the coverage of the main scientific and branch areas of agricultural scientists cooperation of the Ukrainian and Moldavian SSRs under the auspices of the Southern Branch of V. I. Lenin All-Union Academy of Agricultural Sciences, its activities and contribution to the development of agricultural science.

The Main Material Statement. At the end of the 1960s, for the progress in agriculture in the USSR, a considerable attention was paid to the development of agricultural science and its effective management. To coordinate the activities of research institutions, regional branches of V. I. Lenin All-Union Academy of Agricultural Sciences were established (Central State Archives of the Public Associations of Ukraine, f. 1, d. 32, c. 127, p. 24). In accordance with the resolutions of the Council of Ministers of the USSR of January 12, 1969, No. 943 and the Council of Ministers of the USSR of January 5, 1970, No. 1 its Southern branch began to operate (CSAPA of Ukraine, f. 1, d. 32, c. 85, p. 53).

The newly established scientific methodical and coordination center under the leadership of V. F. Peresypkin, the corresponding member of VASHNIL, united research institutions and institutions of higher education in agriculture, water, forestry, economy, processing industry of the Ukrainian and Moldavian SSRs. (Central State Archives of the Higher Authorities and Administration of Ukraine, f. P-2, d. 13, c. 4255, p. 93). Under the leadership of the Southern Branch there were 19 research institutes with research stations and seed farms of the Ministry of Agriculture of the Ukrainian SSR (Nyzhnyk, 2014, p. 179). There were 7 research institutes of the Ministry of Agriculture of the Moldavian SSR, on the basis of which research and production associations were established. There were also 8 All-Union research institutes in the region, 5 of which were directly subordinated to VASHNIL, 3 - to the Ministry of Agriculture of the USSR. There were 5 research institutes and 37 research stations of other departments. In the region significant research work was conducted at the departments of 19 branch institutions of higher education (Kuzmenko, 1973b, p. 130). Thus, 
the cooperation of the Ukrainian and Moldavian agricultural scientists took place on a strong scientific and technical base, which included research institutions, research and production associations, experimental farms and higher education institutions located in different soil and climatic conditions. Although some differences in their subordination somewhat complicated the organization and coordination of researches.

Elected in 1972, the first staff of the Presidium of the Southern Branch of VASHNIL numbered 17 people, 13 of whom represented science and production of the Ukrainian SSR, 4 - the Moldavian SSR. On the Ukrainian side, scientific and methodological guidance was provided by academicians and corresponding members of VASHNIL: H. O. Bohdanov, P. O. Vlasiuk, L. H. Hrom-Maznichevsky, Y. A. Danylenko, H. V. Zvereva, M. V. Kuzmenko, V. M. Remeslo. Among the Moldavian scientists there worked the following ones: M. F. Lupashko, a director of the Moldavian Institute of Breeding, Seed Production and Agricultural Engineering of Field Crops; A. S. Subotovych, Vice-Rector of the Chisinau Agricultural Institute; K. V. Moraru, a director of the Institute of Plant Physiology and Biochemistry of the Academy of Sciences of the Moldavian SSR (Composition of the Presidium of the Southern Branch of the VASHNIL, 1972, p. 113).

Doing the research work was coordinated by sections and problem coordinationmethodical commissions of the Southern branch. There were the following scientific and branch sections: agriculture and crop production; forestry, hydraulic engineering and land reclamation; animal husbandry and veterinary medicine; mechanization and electrification; economy and organization of agriculture. There was also a section for planning and coordination of research (Bazhan, (Ed.), 1982, p. 325). In total, there were 39 problem coordination and methodological commissions in various scientific and branch areas. In particular, agronomic -21 ; animal husbandry and veterinary medicine -6 ; mechanization and electrification - 6; economy and organization of agriculture - 6 (Chernysh, 2012). The coordination and methodological commissions included leading agricultural scientists, as well as specialists from the agricultural authorities of the Ukrainian and Moldavian SSRs (CSAHAA of Ukraine, f. 5176, d. 1, c. 55, p. 1).

Thus, the research guidance consisted in the successful cooperation of agricultural specialists. The knowledge and technology exchange contributed to the development of technical progress in agriculture (Lykholat, 2017, p. 157). The methods of scientific research were improved, achievements of science and the best practices in the leading scientific and branch areas were generalized (Basyl \& Kryzhanivskyi, 2019, p. 174). Cooperation with the Academies of Sciences, Ministries and Departments of the Ukrainian and Moldavian SSRs was strengthened in the direction of organizing joint scientific research, scientific and technical relations with foreign academies, research institutions and institutions of higher education (CSAPA of Ukraine, f. 1, d. 32, c. 85, p. 51).

At the sections there were analyzed the annual research plans, annual reports of research institutions, proposals for the agricultural production implementation of the results (CSAHAA of Ukraine, f. 5176, d. 1, c. 964, p. 4). The directions of coordination and methodical commissions' activity efficiency were analyzed (CSAPA of Ukraine, f. 1, d. 32, c. 127, p. 25). The research was planned in different scientific and branch directions taking into account zonal features, specialization and concentration of agricultural production in the Ukrainian and Moldavian SSRs (CSAPA of Ukraine, f. 1, d. 32, c. 513, p. 77).

The Ukrainian and Moldavian scientists introduced new high-yielding sorts and hybrids of agricultural crops into agricultural production. For example, in the Ukrainian Institute of 
Crop Production, Selection and Genetics, A. D. Humeniuk, O. M. Riabota submitted to the state probation a sort of sunflower, which exceeded the standard sort in oil significantly. At AllUnion Selection and Genetic Institute P. F. Harkavy, F. H. Kyrychenko, O. O. Sozinov selected drought-resistant sorts of winter wheat, rye and spring barley, which were grown in Odesa region of the Ukrainian SSR and arid regions of the Moldavian SSR. Analogs of maize hybrids with high lysine content were selected (Peresypkin, 1972, pp. 94-95). Under the leadership of V. M. Remeslo, scientists of Myronivka Institute of Wheat Selection and Seed Production submitted 4 high-quality sorts of winter wheat to the state probation. At All-Union Institute of Sugar Beets M. A. Hrekov, M. O. Nehovsky selected hybrids of sugar beets on a sterile basis (Ozeranskyi, 1976, pp. 109-110). At All-Union Institute of Maize I. S. Hodulian, B. P. Sokolov elaborated industrial technology for growing corn at farms in the Ukrainian and Moldavian SSR. N. S. Kalashnyk selected a hybrid of sorghum with a high level of drought resistance and relatively low soil requirements to be grown in steppe areas (Kuzmenko, 1973a, p. 146).

The selection work of the Moldavian scientists was aimed at creating new forms of legumes, which combined precocity, high yield and quality. In particular, scientists of the Moldavian Institute of Selection, Seed Production and Agricultural Engineering of Field Crops submitted to the state probation sorts of peas, which in terms of grain yield exceeded the zoned ones significantly. A promising soybean sort with $43 \%$ protein in the grain was selected. At the end of the 1970s, plant breeders of the Moldavian SSR submitted 24 sorts and hybrids of agricultural crops, 9 sorts of fruit berries and 9 sorts of grapes for sort probation (Peresypkin, 1972, p. 94).

Thus, the international cooperation facilitated the achievements of the Ukrainian and Moldavian plant breeders in selecting high-yielding sorts of cereals, legumes, industrial and vegetable crops. Systematic exchange of seed material was carried out among research institutions, which accelerated the selection process and increased its efficiency.

Research work on the formation of intensive farming systems in the Ukrainian and Moldavian SSRs proved to be successful. The following people worked on this issue: V. O. Pastushenko from the Ukrainian Institute of Agriculture, P. T. Kibasov from the Moldavian Institute of Selection, Seed Production and Agricultural Engineering of Field Crops, Ya. S. Konstantynov from the Moldavian Institute of Irrigated Agriculture and Vegetable Growing (CSAHAA of Ukraine, f. 5176, d. 1, c. 55, p. 13). Scientists elaborated farming systems and a set of agronomic measures to get rid of drought. The complex included the introduction of scientifically reasonable crop rotations, basic and pre-sowing cultivation, organo-mineral fertilizers, new high-yielding sorts and hybrids (Kuzmenko, 1973a, p. 144). In order to provide better moisture for winter wheat, corn, sunflower and sugar beet crops in the southern zone of the Moldavian SSR, it was recommended to keep to agricultural techniques and optimal sowing dates of certain sorts (Cibasov \& Bondarenco, 1976, p. 230). Scientists determined the feasibility of using fields in the central and northern territorial zones of the Moldavian SSR. They determined a better sowing of corn after cereals, sugar beets, sunflowers. Due to the fact that sunflower dries the soil too much to a great depth, it was recommended to sow corn after it. Corn better absorbs moisture from the upper layers of the soil (Cibasov \& Bondarenco, 1990, p. 138). The Moldavian colleagues determined the best plants after which winter wheat was sown. In the south of the Moldavian SSR those were fields with a mixture of oatmeal, corn for green fodder with soybeans, peas with oats (Cibasov at al., 1982). The peculiarities of the main and pre-sowing tillage in the southern zone of the Moldavian SSR were found out. The expediency of complex application of organic and mineral fertilizers was determined, which provided a significant increase in winter wheat 
grain (Cibasov at al., 1977). More than 150 research institutions of the Belarusian, Armenian, Georgian, Estonian, Latvian, Lithuanian, Moldavian, Ukrainian SSRs and RSFSR cooperated in the study of sugar beet growing efficiency (CSAHAA of Ukraine, f. P-27, d. 20, c. 183, p. 12).

The programme and research methodology elaborated by the Ukrainian and Moldavian scientists on the objective "To develop scientific bases and practical recommendations of intensive specialized crop rotations for the Ukrainian and Moldavian SSRs" became fundamental (Pastushenko at al., 1979). The method of doing research in crop rotations based on determining soil fertility was recommended (Pastushenko at al., 1979, p. 22). According to the results of research, advanced technologies of growing grain, technical, fodder and vegetable crops were introduced into production.

M. F. Lupashka, a director of the Moldavian Research Institute of Selection, Seed Production and Agricultural Engineering of Field Crops, updated establishing of specialized research and production associations on the basis of research institutes. Such associations "Selection", "Hybrid", "Dniester" were one of the forms of science and production integration. They included farms that carried out production processes on a scientific basis. Instead, research institutes solved problems that arose at farms (Ozeranskyi, 1976, p. 108). In the mid-1980s, the experimental farms that were the part of associations became significant. They widely introduced industrial tillage technologies into production, distributed zoned sorts and hybrids (CSAHAA of Ukraine, f. 5176, d. 1, c. 1390, p. 97).

Peculiarities of irrigated agriculture and use of irrigation regimes under arid conditions of the Ukrainian and Moldavian SSRs were studied by the following scientists: I. O. Babenko, V. I. Ostapov from the Ukrainian Institute of Irrigated Agriculture, Ya. S. Konstantynov from the Moldavian Institute of Irrigated Agriculture and Vegetable Growing (Kovalenko, 2014, p. 189). They recommended effective irrigation regimes for farms in the southern regions (Kuzmenko, 1973b, p. 131). By the method of individual selection the Moldavian colleagues selected sorts of haricot beans, which under irrigation exceeded the ordinary sorts in yield, chemical and technological properties (Peresypkin, 1972, p. 95).

Researches from other fields of science were significant. For example, the role of protective afforestation in the fight against drought and soil erosion was determined by V. I. Koptev from the Ukrainian Institute of Forestry and Agroforestry Reclamation. He elaborated and implemented a system of protective forest plantations, which included field protective forest strips and anti-erosion plantations (Kuzmenko, 1973a, p. 147). At the Ukrainian Institute of Soil Science and Agrochemistry, B. S. Nosko worked out measures to preserve and further increase soil fertility on the basis of a rational use of fertilizers. At the Ukrainian Institute of Plant Protection, V. P. Vasyliev elaborated an integrated system of crop protection, which was based on a combination of agronomic, chemical and biological measures to control pests, diseases and weeds (Ozeranskyi, 1976, p. 109).

A significant amount of joint research was done in the direction of mechanization and electrification of agriculture. For example, at the Ukrainian Institute of Mechanization and Electrification, E. I. Khrapach elaborated the technology for the current harvesting of cereals and legumes with simultaneous grinding and shredding of straw. Scientists elaborated an organizational scheme for the development of the repair base of agriculture in the Ukrainian and Moldavian SSRs, created new models of tractor equipment, dispatching tools, technical diagnostics of machines and repair of parts. Machine for engraftment grapes passed the state testing and was recommended for mass production. This machine was designed at the Moldavian Institute of Horticulture, Viticulture and Enology. The machine provided twice as many engraftments compared to manual labour (Peresypkin, 1972, p. 96). 
Particularly difficult tasks were solved in animal husbandry. Along with the technologies of livestock production, intra-industry specialization was elaborated. For example, together with scientists from the countries of the Council for Mutual Economic Assistance - the People's Republic of Bulgaria, the German Democratic Republic and the Hungarian People's Republic there were elaborated technologies for the construction of pig farms and fattening pigs farms. The construction was carried out in the Moldavian SSR (Kuzmenko, 1973b, p. 132). At the Institute of Animal Husbandry of the Forest-Steppe and Polissia of the Ukrainian SSR, H. O. Bohdanov, the Institute of Agriculture and Animal Husbandry of the Western Regions of the Ukrainian SSR, V. D. Horb, V. G. Lapchuk, F. Yu. Palfiy bred highly productive domestic breeds of cattle and pigs for meat. At the Ukrainian Institute of Feed, I. P. Proskura developed zonal systems of feed production, taking into account the specialization of animal husbandry. The problem of protein deficiency in feed was solved by the rational use of plant resources, mycological and chemical synthesis (Ozeranskyi, 1976, p. 109).

The Ukrainian and Moldavian colleagues created a significant gene pool of different lines and breeds of egg and meat chickens, turkeys, ducks, geese. A system for collecting, accumulating and genetic mathematical analysis of poultry breeding data at state breeding poultry farms was developed and implemented. At the Ukrainian Institute of Poultry there were bred highly productive egg hens and meat turkeys. A new synthetic line of high-yielding meat and egg chickens and musk ducks was bred in the branch of the Moldovan Institute of Animal Husbandry and Veterinary Medicine. A set of measures for diagnosis, prevention and control of diseases was developed (Meeting of the Presidium of the Southern Branch of the VASHNIL, 1983, p. 88). Thus, the Ukrainian and Moldavian breeders-geneticists carried out a systematic exchange of research results with scientists from other countries. Their international cooperation contributed to the growth of livestock productivity, improving the epizootic situation.

The economic direction of research was developed significantly. For example, at the Ukrainian Institute of Economics and Organization I. I. Lukinov, O. O. Storozhuk worked out a system of rational management in the Ukrainian and Moldavian SSRs. The system operated on the basis of integration, specialization and concentration of production, taking into account the economic evaluation of soil, provision of production assets and labour resources (Ozeranskyi, 1976, p. 109). On the basis of advanced technological processes, recommendations for the improvement of production types of branch enterprises operating in different soil and climatic zones of the Ukrainian and Moldavian SSRs were developed (CSAHAA of Ukraine, f. 5176, d. 1, c. 55, pp. 3-4).

During the years of scientific and methodological leadership of the Southern branch of VASGNIL the material and technical base grew, scientific technologies and experience of agrarian scientists were developed (CSAHAA of Ukraine, f. 5176, d. 1, c. 55, p. 5). Despite the achievements of agricultural science, much of the theoretical and methodological developments were not widely used in the practical production of the Ukrainian and Moldavian SSRs. (Verhunov, 2012, p. 220). In 1990, in connection with the need to develop basic research on the basis of the Southern Branch of VASHNIL there was established the Ukrainian Academy of Agrarian Sciences (nowadays - the National Academy of Agrarian Sciences of Ukraine) (Orekhivskyi, 2018, p. 332). It continued to function as a higher scientific methodical and coordination center for the development of agricultural science in Ukraine.

The Conclusions. The cooperation of the Ukrainian and Moldavian agricultural scientists under the leadership of the Southern Branch of VASHNIL took place on a strong material 
and technical base, which included research institutions, higher education institutions, specialized research and production associations and experimental farms. Due to the effective coordination of research work by sections and problem coordination and methodological commissions, research was carried out in the relevant scientific and sectoral areas, taking into account the zonal characteristics, specialization and concentration of agricultural production in the Ukrainian and Moldavian SSRs. Successful cooperation of scientists ensured the implementation of research based on the systematic exchange of information, which accelerated the process and increased the efficiency of research under different soil and climatic conditions. It contributed to the development of highly efficient technologies in agriculture and crop production, breeding and seed production, land reclamation and agroforestry, animal husbandry and veterinary medicine, mechanization and electrification, economy and organization of agricultural production. Under the leadership of the Southern Branch of VASHNIL, the results of research work of the Ukrainian and Moldavian scientists gained international recognition among scientists of the Belarusian, Armenian, Georgian, Estonian, Latvian, Lithuanian SSR and RSFSRs. Animal husbandry production technologies were widely used in the countries of the Council for Mutual Economic Assistance - the People's Republic of Bulgaria, the German Democratic Republic and the Hungarian People's Republic. This contributed to the growth of the efficiency of domestic scientific research, which was not inferior to foreign research in terms of its achievements. Owing to significant achievements, the Ukrainian agricultural scientists increased their international prestige and confirmed that domestic science occupied an honorable place abroad.

Acknowledgments. We are sincerely grateful to the directors and staff of the Central State Archives of Ukraine and the Central State Archives of Ukraine for their assistance in processing archival documents and materials.

The Funding. The authors received no financial support for the research, authorship, and/or publication of this article.

\section{BIBLIOGRAPHY}

Basyl, S. M. \& Kryzhanivskyi, V. M. (2019). Spivpratsia vchenykh Vsesoiuznoho naukovodoslidnoho instytutu lubianykh kultur iz naukovtsiamy Uhorskoi Narodnoi Respubliky u druhii polovyni 1970 - 1980-kh rr. [The Collaboration between the All-Union Research Institute of Fiber Crops and Scientists from Hungarian People's Republic during the Second Half of the 1970s and 1980s]. Storinky istorii, 48, 171-185. doi: 10.20535/2307-5244.48.2019.176391. [in Ukrainian]

Bazhan, M. P. (Ed.). (1982). Pivdenne viddilennia Vsesoiuznoi akademii silskohospodarskykh nauk imeni V. I. Lenina [Southern Branch of the All-Union Academy of Agricultural Sciences named after V. I. Lenin]. Ukrainska Radianska Entsyklopediia. (Vol. 8, p. 325). Kyiv: Holov. red. URE. [in Ukrainian]

Chernysh, O. O. (2012). Pivdenne viddilennia Vsesoiuznoi akademii silskohospodarskykh nauk im. V. I. Lenina: orhanizatsiina struktura ta napriamy diialnosti [Southern Branch of V. I. Lenin All-Union Academy of Agricultural Sciences: organizational structure and activities]. Istoriia nauky i biohrafistyka, 3. URL: http://inb.dnsgb.com.ua/2012-3/12_chernysh.pdf. [in Ukrainian]

Cibasov, P. T. \& Bondarenco, Iu. M. (1976). Răsărita. Călăuza agricultorului. Chișinău: Cartea Moldovenească, 228-231. [in Romanian]

Cibasov, P. T. \& Bondarenco, Iu. M. (1990). Răsărita. Călăuza agricultorului. Chişinău: Cartea Moldovenească, 133-147. [in Romanian]

Cibasov, P. T., Untilă, I. P., Vronschih, M. D., Snegur, M. I., Naconecinaia, Z. I., Zagorcea, C. L. et al. (1977). Recomandări cu privire la cultivarea soiurilor intensive de culturi de toamnă. Chișinău: Cartea Moldovenească, 23. [in Romanian] 
Cibasov, P., Golban, N., Bondarenco, Iu., Vetrova, E., Nica, L., Lisovschi, A. at al. (1982). Recomandări cu privire la cultivarea mazării pe bază industrial. Chişinău: Cartea Moldovenească, 20. [in Romanian]

Kovalenko, N. P. (2014). Stanovlennia ta rozvytok naukovo-orhanizatsiinykh osnov zastosuvannia vitchyznianykh sivozmin u systemakh zemlerobstva (druha polovyna XIX - pochatok XXI st.): monohrafiia [Formation and Development of Scientific and Organizational Bases of Domestic Crop Rotations Application in the Systems of Agriculture (the second half of the XIXth - the beginning of the XXIst century): monograph]. Kyiv: TOV "Nilan-LTD”, 490 p. [in Ukrainian]

Kuzmenko, M. V. (1973a). Yuzhnye raiony Ukrainy i Moldaviia [Southern Regions of Ukraine and Moldova]. Vestnik selskokhoziaistvennoi nauki, 5(209), 143-147. [in Russian]

Kuzmenko, M. V. (1973b). Obshchee sobranie akademikov i chlenov-korrespondentov VASKhNIL [General Meeting of Academicians and Corresponding Members of the VASHNIL]. Vestnik selskokhoziaistvennoi nauki, 10(214), 130-135. [in Russian]

Lykholat, A. O. (2017). Istoriia obminu znanniamy i tekhnolohiiamy (na prykladi mizhnarodnoho transferu) [The History of Knowledge Formation and Development on the Case Study of Technological Interchange]. Storinky istorii, 44, 156-167. doi: 10.20535/2307-5244.44.2017.105464. [in Ukrainian]

Nyzhnyk, S. V. (2014). Akademik V. F. Peresypkin - fundator Pivdennoho viddilennia VASKhNIL [Academician V. F. Peresypkin - the Founder of the Southern Branch of the VASHNIL]. Istoriia nauky i tekhniky, 5, 178-188. [in Ukrainian]

Orekhivskyi, V. D. (2018). Rozvytok orhanichnoho zemlerobstva v URSR u konteksti naukovoorhanizatsiinoi diialnosti Pivdennoho viddilennia VASKhNIL (1969 - 1990) [Development of Organic Farming in the USSR in the Context of Scientific and Organizational Activities of the Southern Branch of the VASHNIL (1969 - 1990)]. Molodyi vchenyi, 2(54), 330-334. [in Ukrainian]

Ozeranskyi, L. A. (1976). Richni zbory vchenykh rehionu Pivdennoho viddilennia VASKhNIL [Annual Meeting of Scientists of the Region of the Southern Branch of the VASHNIL]. Visnyk silskohospodarskoi nauky, 4(221), 105-113. [in Ukrainian]

Pastushenko, V. O., Zakharchenko, I. H., Hodulian, I. S., Hrekov, M. A., Kibasov, P. T. \& Buzmakov, V. V. (1979). Prohramma i metodika issledovanii po zadaniiu "Razrabotat nauchnye osnovy i prakticheskie rekomendatsii po intensivnym spetsializirovannym sevooborotam dlia Ukrainskoi i Moldavskoi SSR" [Research Programme and Methodology for the Objective "To develop scientific foundations and practical recommendations for intensive specialized crop rotations for the Ukrainian and Moldavian SSR"]. Moskva: Tipohrafiia VASKhNIL, 38. [in Russian]

Peresypkin, V. F. (1972). Sessiia Vsesoiuznoi akademii selskokhoziaistvennykh nauk imeni V. I. Lenina: vystupleniia na plenarnykh zasedaniiakh [Session of V. I. Lenin All-Union Academy of Agricultural Sciences: speeches at plenary sessions]. Vestnik selskokhoziaistvennoi nauki, 6(198), 94-96. [in Russian]

Sklad Prezydii Pivdennoho viddilennia VASKhNIL. (1972). Sklad Prezydii Pivdennoho viddilennia VASKhNIL [Composition of the Presidium of the Southern Branch of the VASHNIL]. Visnyk silskohospodarskoi nauky, 9, 113. [in Ukrainian]

Tsentraljnyj derzhavnyj arkhiv hromadskykh obiednan Ukrainy [Central State Archives of the Public Associations of Ukraine - CSAPA of Ukraine]

Tsentraljnyj derzhavnyj arkhiv vyshhykh orghaniv vlady ta upravlinnja Ukrainy [Central State Archives of the Higher Authorities and Administration of Ukraine-CSAHAA of Ukraine]

Verhunov, V. A. (2012). Silskohospodarska doslidna sprava v Ukraini vid zarodzhennia do akademichnoho isnuvannia: orhanizatsiinyi aspekt [Agricultural Research in Ukraine from Inception to Academic Existence: organizational aspect]. Kyiv: Ahrarna nauka, 416 p. [in Ukrainian]

Zasidannia Prezydii Pivdennoho viddilennia VASKhNIL. (1983). Zasidannia prezydii Pivdennoho viddilennia VASKhNIL [Meeting of the Presidium of the Southern Branch of the VASHNIL]. Visnyk silskohospodarskoi nauky, 8, 87-88. [in Ukrainian]

The article was received May 06, 2020. Article recommended for publishing 31/08/2021. 